\title{
Discussion on the Enlightenment of Dewey's Educational Thoughts on the Reform of Early Childhood Education in China
}

\author{
Lina Zhang ${ }^{1}$, Dongqing $\mathrm{Bai}^{2}$, Yixiao Tong ${ }^{3}$ \\ 'Teachers' College Shenyang University \\ Shenyang, China \\ 'Teachers' College Shenyang University \\ Shenyang, China \\ 3Teachers'Kindergarten Tiexi District \\ Shenyang , China
}

Keywords: Early childhood education reform; Dewey; Educational thoughts

\begin{abstract}
The purpose of this paper is to conduct a series of researches on the enlightenment brought by Dewey's educational thoughts to the reform of early childhood education in China, and hope to have a certain development and promotion effect on the reform of early childhood education in China. This paper mainly uses the literature method to introduce the background of Dewey's educational thoughts, deeply analyzes the theoretical basis of Dewey's educational thoughts, expounds the content of Dewey's educational thoughts, and finally puts forward the enlightenment of Dewey's educational thoughts on China's early childhood education reform, that is to pay attention to the early moral education of young children; focus on the curriculum reform of kindergartens; pay attention to the methods of early childhood education; lay emphasis on the cultivation of teacher-student relationship. The innovation of this paper lies in the fact that all aspects of China's early childhood education reform are based on Dewey's educational thoughts, and different reforms of different aspects are divided and dissected to promote the development of China's early childhood education to a higher level, adhering to a more advanced concept into the future.
\end{abstract}

\section{Introduction}

In China, preschool education reform involves a wide range of aspects. This paper mainly solves a series of problems of the preschool education reform in China through the relevant content of Dewey's educational thoughts, and applies the enlightenment brought by the guidance of Dewey's relevant educational thoughts for the preschool education reform to the frontline education of kindergartens in China, so that the preschool education in China is sufficiently developed and improved.

\section{Background of Dewey's educational thoughts}

\subsection{Introduction to Dewey}

John Dewey (1859.10.20-1952.6.1), a philosopher, psychologist, educator, and a leading figure in the philosophy of pragmatism in the United States ${ }^{[1]}$. His literatures are numerous and involved in very broad fields. In 1886 Dewey published the first psychology textbook. His series of educational thoughts had promoted the progress and development of pragmatic philosophy, and also made great contributions to humanities research.

\subsection{Times background of Dewey's educational thoughts}

\subsubsection{Bourgeois social contradictions deepening}

In 1862, the Lincoln government implemented a series of revolutionary measures such as the liberation of slaves and the implementation of the "Homestead Act". The contradiction between the 
bourgeoisie and the slave owners had deepened day by day. The ultimate result was that the bourgeoisie had defeated the slave owners of the southern plantations, which means in 1859 , when Dewey was born, the economy of the United States had embarked on a new era of rapid development. Since then, the United States undergone two world wars and experienced a major economic crisis. The development of capitalism inevitably played a progressive role in the development of Dewey's thoughts.

\subsubsection{Industrialization of urbanization}

By the end of the 19th century, during the youth of Dewey, the American economy caught up with old capitalist countries such as Germany and the United Kingdom, became the number one industrial power in the world, completed industrialization and urbanization, and entered the development stage of modern capitalism, that is, monopoly capitalism. The development of the economy will inevitably lead to the backwardness of traditional educational concepts. Dewey's progressive thoughts has gradually surfaced, and some modern ideas that were contrary to traditional educational ideas have gradually emerged.

\subsubsection{Impact of the immigration boom}

In the 19th century, a large number of immigrants came to the North American continent to open up new life from Europe and other places. Americans were facing new challenges that how to turn lots of immigrants into Americans? Hollis Man proposed to turn American schools into public education institutions and turn the immigrants into Americans while cultivating a lot of qualified laborers for industrial society, so as to consolidate the foundation of the United States. Therefore, in the era of Dewey's life, American education had also undergone major changes ${ }^{[2]}$.

\subsubsection{Challenges to traditional education}

Influenced by religious factors, at the end of the $19^{\text {th }}$ century American schools emphasized authority and discipline, and school education was full of control. As progressive people such as Dewey in the United States went to Europe for study, some emerging educational ideas that emphasized individuality and rationality had gradually spread to the United States, laying a solid ideological foundation for American education reform. Dewey's educational thoughts gradually replaced traditional educational thoughts and brought infinite hope for the "new world".

\section{The theoretical basis of Dewey's educational thoughts}

\subsection{Pragmatic philosophy}

Generally speaking the pragmatic philosophy is that the final things, harvests, effects, and facts are considered, instead of the first things, principles, categories, etc. Dewey was honored as the "parent of the pragmatic sacred family", showing the far-reaching influence of pragmatism on Dewey. The representatives of pragmatic philosophy were born in the United States, and its activity center had never left the land of the United States. Americans liked to hunt for their pursuits freely and chased their own interests, which made Americans more willing to accept new ideas and concepts, and was the key to the formation of Dewey's thoughts.

\subsection{Theory of democracy}

Dewey wrote a book entitled "Democracy and Education", which shows that the influence of democratic ideology on Dewey is profound and significant. Dewey believed that "democratism is not only a form of government, while it is first and foremost a way of united life, a way of sharing experiences together." ${ }^{[2]}$ Dewey emphasized that a democratic society needs democratic education, and school education should be a democratic education. If democracy is a habit of living through education, a way of life, then this habit or method depends on education.

\subsection{Theory of European Naturalism}

The theory of naturalism sprouted in the thoughts of ancient Greek philosophers and developed rapidly in modern society. With the development of the European Renaissance, Rousseau proposed that education should return to nature, adapt to nature, and emphasize the natural adaptation 
principle of education. The term "natural", in the eyes of Rousseau, mainly referred to the nature of children. Education should follow the natural process of the development of a growing person, consider its age characteristics, and adapt to its own nature to education. The influence of the thoughts that education was in conformity with nature was deeply rooted in Dewey, and his series of educational thoughts were lied on this foundation.

\subsection{Darwin's theory of evolution}

Dewey was born on October 20, 1859. This year, Darwin published his book "On the Origin of Species" and proposed the thought of evolution. The thought of evolution that biology is from simple to complex, gradually evolved from low to high, and the theory of evolution that is natural selection and survival of the fittest, had become one of the three major discoveries of the 19th century natural science recognized by the academic and ideological circles. The emergence of evolutionary theory had subverted the world of human beings. The "new world" brought about by the theory of evolution was the era of Dewey's life, and the concept he accepted was also subversive.

\section{Main content of Dewey's educational thoughts}

\subsection{Moral education thoughts}

Dewey divided ethics into three parts, namely knowledge, emotion and ability. In Dewey's view, morality is the unity of individual social emotion, social knowledge and social abilities. The purpose of school moral education is to cultivate the natural people in a society, who are both naturally grown and social persons combining social emotions, knowledge and abilities that are of interest to social relations and social control. Therefore, all educational activities of the school serve the purpose of morality. They advocate to combine moral education with social life and believe that the various factors in the school are combined to form an indirect moral education. In the way of moral education, Dewey put forward the idea of moral education through school life, various textbooks and teaching methods. Schools must shoulder the heavy responsibility of moral education, regard the cultivation of students' morality as one of the most extensive purposes of school teaching and training, and infiltrate moral education into all the work of the school.

\subsection{Educational and teaching principles}

Dewey believes that "education is life, education is growth, and education is experience transformation" [3]. Dewey considers that the school is not only a place for students to learn knowledge, but also a paradise for students to live. Only by subtly changing the way in which knowledge is taught can teachers turn "school" into "society".

At the same time, Dewey holds the view that the experience gained through rote memorization is not an experience, and education that can promote the development of human personality can be regarded as experience. The transformation of experience is the internalization of experience, and then the internalized experience is transferred to skills to gain new experience. In terms of teaching methods, Dewey put forward "learning from doing", attached importance to the role of practice in education and learning, and considered that the importance of practice was far greater than the theory ${ }^{[3]}$.

\subsection{Children's game ideas}

In Dewey's educational philosophy, he put forward an important idea that games are inseparable from education and art and education and art cannot run without games. Dewey believes that school education should make full use of children's game talents, and games can greatly promote the development and improvement of children's logical ability and interpersonal skills. For young children, the game should run through the children's one-day learning, sports, and life, and be integrated into all the courses. 


\subsection{Children central ideas}

Another subversive theory put forward by Dewey in his educational thoughts is the "new three-center theory", namely the children center, the activity center, and the experience center. "The focus of our education is changing and children are the sun, around which educational facilities are revolving, centering on children to organize." The advocated children center respects children's interests, and teachers are the mentor and guide of children's interests

\section{Enlightenment of Dewey's educational thoughts on the reform of early childhood education in China}

\subsection{Attention to early childhood moral education}

According to Dewey's moral education thoughts, the moral education for young children is a continuously developing process. Moral education should be started from the young children and persisted in. Firstly, young children are educated on patriotism and cultivated on their patriotic feelings. Secondly, young children are cultivated on interest in labor and positive attitude towards life, assisting young children in building mutual-aid awareness and developing a spirit of friendship. Educators must follow the growth rules of young children, carefully care for the curiosity of young children, and organically combine teaching with labor and games to grasp every educational opportunity in life. At the same time, family education is also the key to early childhood moral education.

\subsection{Focus on kindergarten curriculum reform}

First of all, in the curriculum, the game activities serve as a carrier to set up more hands-on courses. The development of children's hands-on ability, operational ability and logical thinking ability is the focus of early childhood improvement.

Second, the one-day life in the kindergarten is a curriculum activity of the kindergarten. In the kindergarten activities, the teachers only play a guiding role to help the children freely integrate into the "small society" of the kindergarten. Finally, the principle of "learning from doing" is implemented into the curriculum reform. Simply speaking the concept advocated by Dewey is to learn by doing, based on vividness, and start with practical operations to obtain knowledge and experience $^{[4]}$.

\subsection{Focus on early childhood education methods}

According to Dewey's thoughts on children's games, "toys are the angels of young children, and games are the companions of young children". Therefore, games are very popular among young children, and the children grow up and progress in games and in playing. Games are an invisible big classroom, while curiosity and imagination are the driving force for children to actively learn. In order to stimulate their strong learning motivation, using toys and games to educate them is the most acceptable and most enjoyable learning mode for young children. Every time children play, they may have different ways of playing and different ideas, invisibly cultivating their flexible imagination and creativity. The game method can also help children gradually form a sense of rules and establish intimate peer relationships. In addition, children are more acceptable the truth told in games $^{[5]}$.

\subsection{Pay attention to the cultivation of teacher-child relationship}

Teachers' attitudes towards young children will directly influence the affinity relationship between children and teachers. Teachers should first go to the middle of children, pay attention to them from the perspective of young children, create a good psychological atmosphere with love, and let the children open their hearts, like their teachers and believe in their way. Secondly, teachers should help young children to establish good peer relationships, guide children to deal with contradictions themselves, help them solve problems properly, and form an atmosphere that solves problems with children as the center. Thirdly, kindergarten teachers should strive to build a good relationship 
between teachers and children by respecting young children and treating children equally. Teachers should proceed from the actual situation of children and teach students according to their age characteristics and individual differences.

\section{Conclusions}

Based on Dewey's educational thoughts, this article gives a rough analysis of the enlightenment of Dewey's educational thoughts on early childhood reform in China. The research conclusions of this paper mainly include the following points: attaching importance to the early moral education for young children; focusing on the curriculum reform of kindergartens; laying emphasis on the methods of early childhood education; paying attention to the cultivation of teacher-student relationship. The reform of early childhood education in our country needs to be further improved, with a lot of room for improvement in both theory and practice.

\section{References}

[1] Wang Linghao. Introduction to Dewey's Educational Works. [M]. Jilin Literature and History Press, 2013.

[2] Richard Prong (Interpreter Wu Jian). Jone Dewey [M]. Hei Longjiang Education Press, 2016.

[3] Huo Liyan. Theory and Practice of Preschool Education[M]. Huadong Normal University Press , 2015.

[4] Zhang Jie. The Enlightenment of Dewey's Educational Thoughts on the Preschool Curriculum [J], Periodical Teachers ,2017, 04.

[5] Zheng Yile. The Enlightenment and successful experiences of the Reform of Preschool Education in England [J]. Periodical Education Exploration, 2016, 04. 